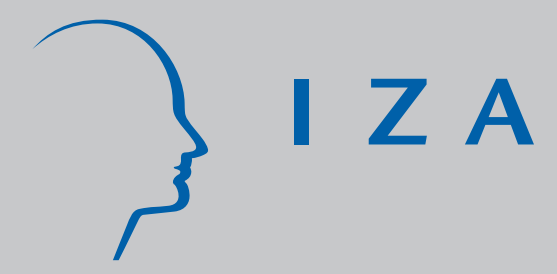

IZA DP No. 536

Pension Taxes versus Early Retirement Rights

Mike Orszag

Dennis Snower

J uly 2002 


\title{
Pension Taxes versus Early Retirement Rights
}

\author{
Mike Orszag \\ Watson Wyatt and IZA Bonn \\ Dennis Snower \\ Birkbeck College, University of London, \\ CEPR and IZA Bonn
}

Discussion Paper No. 536 July 2002

\author{
IZA \\ P.O. Box 7240 \\ D-53072 Bonn \\ Germany \\ Tel.: +49-228-3894-0 \\ Fax: +49-228-3894-210 \\ Email: iza@iza.org
}

This Discussion Paper is issued within the framework of IZA's research area Welfare State and Labor Market. Any opinions expressed here are those of the author(s) and not those of the institute. Research disseminated by IZA may include views on policy, but the institute itself takes no institutional policy positions.

The Institute for the Study of Labor (IZA) in Bonn is a local and virtual international research center and a place of communication between science, politics and business. IZA is an independent, nonprofit limited liability company (Gesellschaft mit beschränkter Haftung) supported by the Deutsche Post AG. The center is associated with the University of Bonn and offers a stimulating research environment through its research networks, research support, and visitors and doctoral programs. IZA engages in (i) original and internationally competitive research in all fields of labor economics, (ii) development of policy concepts, and (iii) dissemination of research results and concepts to the interested public. The current research program deals with (1) mobility and flexibility of labor, (2) internationalization of labor markets, (3) welfare state and labor market, (4) labor markets in transition countries, (5) the future of labor, (6) evaluation of labor market policies and projects and (7) general labor economics.

IZA Discussion Papers often represent preliminary work and are circulated to encourage discussion. Citation of such a paper should account for its provisional character. A revised version may be available on the IZA website (www.iza.org) or directly from the author. 
IZA Discussion Paper No. 536

July 2002

\section{ABSTRACT \\ Pension Taxes versus Early Retirement Rights}

This paper deals with two policy approaches to address the problem of the "pensions time bomb" by influencing private-sector pension provision. In assessing the role of private-sector pensions, it is common to concentrate exclusively on the issue of whether early retirement penalties or late retirement benefits are actuarially fair. We argue that this focus is unbalanced since private-sector pension arrangements have significant implications for governments' finances. When private pensions encourage early retirement, they reduce the number of people paying taxes and increase the number of people supplementing their private pensions through various forms of public support. To induce private-sector pension providers to internalize this externality, we examine two policy responses: taxing private pension receipts of early retirees, and issuing "early retirement rights." The government's receipts from the pension taxes or the sale of early retirement rights are used, in part, to provide employment vouchers for people of pensionable age.

JEL Classification: $\quad \mathrm{H} 1, \mathrm{H} 2, \mathrm{H} 6$

Keywords: pensions, employment, taxes, early retirement

Dennis Snower

Department of Economics

Birkbeck College

University of London

7 Gresse Street

London W1P 1LL

UK

Tel.: +44 (207) 6316408

Fax: +44 (207) 6316416

Email: dsnower@economics.bbk.ac.uk 
This paper provides a simple analysis of alternative policy approaches to deal with the problem of the "pensions time bomb" in the OECD. A steadily increasing proportion of the OECD population is becoming dependent on social security. The sources of this phenomenon are various: (a) The OECD population is aging, sending more people into the pensionable age groups. (b) People are living longer, causing them to draw on their pensions for longer time spans. (c) People are retiring earlier. The mandatory retirement age has fallen in many OECD countries, leading people to draw on their pensions earlier.

As result of these and other forces, the ratio of people aged 65 and over to total employment has been rising steadily over the past three decades. In ten years from now, when the baby-boom generation retires, this ratio is expected to rise at a much faster rate.

This paper deals with two policy approaches to address this problem by influencing private-sector pension provision. In some OECD countries - such as the Netherlands, the U.K., and the U.S. - private-sector pensions play an important role in the social security system. In assessing this role, it is common to concentrate exclusively on the issue of whether early retirement penalties or late retirement benefits are actuarially fair. We argue that this focus is unbalanced since private-sector pension arrangements have significant implications for governments' finances. When private pensions encourage early retirement, they reduce the number of people paying taxes and increase the number of people supplementing their private pensions through various forms of public support. Thus when private pension funds provide pensions in line with people's past contributions, they generally pay nowhere near the full social cost of their pensions. Consequently, their incentives for pension provision are inevitably distorted, giving people excessive incentives to retire early.

Thus, in assessing private-sector pension provision for early retirement, the issue is not just whether the pensions are actuarially fair, but also the degree to which the private-sector pension providers internalize the externality above. Only once this latter issue has been addressed can the public and private pension systems develop smoothly alongside one another, in symbiotic rather than parasitic relationships. 
In thinking about this externality problem, it is useful to draw an analogy between early retirement and pollution. In the presence of transactions costs that prevent agents from achieving a Coasian first-best outcome, both the emitters of pollutants and the providers of private-sector pensions to early retirees face private costs that fall short of social costs. In the case of pollution, there are two straightforward policy responses: imposing pollution taxes and auctioning pollution rights.

In this paper we argue that there are two corresponding policy responses to the early retirement problem: taxing private-sector pensions and auctioning "early retirement rights." In particular, the government can tax the private pension receipts of early retirees, or it can issue a fixed number of early retirement rights that can be auctioned off $b$ the highest bidders.

In one important area, however, the analogy between early retirement and pollution breaks down. When polluters do not bear the full social cost of their emissions, this does not imply that non-polluters' incentives are distorted as well. By contrast, when private-sector pension providers give excessive incentives for people to retire early, this does imply that the remaining people have deficient employment incentives. Thus pension taxes and early retirement rights are in general not sufficient to address the early retirement problem; incentives for employment are required as well.

Thus we argue that the receipts from pension taxes or early retirement rights should be used, in part, to provide employment vouchers for people of pensionable age. In particular, the government can provide subsidies to the private-sector pension providers for granting employment vouchers for their customers. People of pensionable age can take these employment vouchers to their employers, who then receive specified reductions on their payroll taxes.

In addition, since the imposition of pension taxes and the auction of early retirement rights will make early retirement more expensive across the working-age population and thus constitute a regressive tax on the poor, some of the receipts from these policies will need to be used to provide extra income support for the poor.

In short, the policies under consideration may be interpreted as pension tranfers: funds that are currently devoted to early retirement support are transferred to provide employment support. The magnitude of the pension taxes or supply of early retirement 
rights (on the one hand) relative to the employment vouchers and income support for the poor (on the other hand) is to be set so as to achieve the government's desired mix between public and private pension provision, the government redistributive goals, and the government's possible need to recoup some of its current pension obligations.

In analogy with the literature on pollution taxes versus pollution rights, the analysis below shows that when there is uncertainty regarding the marginal social costs or the marginal social benefits from early retirement, the socially optimal decision of whether to use pension taxes or early retirement rights depends on the relative slopes of the marginal social cost and marginal social benefit schedules.

\section{Pension Taxes versus Early Retirement Rights}

For expositional simplicity, it is useful to separate conceptually the decision between pension taxes and early retirement rights from the granting of employment vouchers.

Figure 1 illustrates the effects of the employment vouchers. The number of retired people $P$ is measured on the horizontal axis. For simplicity, let us assume that all people of pensionable age have access to the same wage and same pension benefits. Then horizontal $O C$ line denotes the marginal private opportunity cost of retiring, viz., the wage income minus the pension benefit (in real terms). The downward-sloping MB curve stands for the marginal benefit of retiring. ${ }^{1}$ People have an incentive to retire as long as the marginal benefit from employment $\mathrm{MB}$ exceeds the marginal opportunity cost OC. Thus the equilibrium number of retirees $P^{*}$ lies at the intersection of the $M B$ and $O C$ curves.

\footnotetext{
${ }^{1}$ Here heterogeneous people are ordered along the MB curve, from those with the highest benefits to those with the lowest.
} 


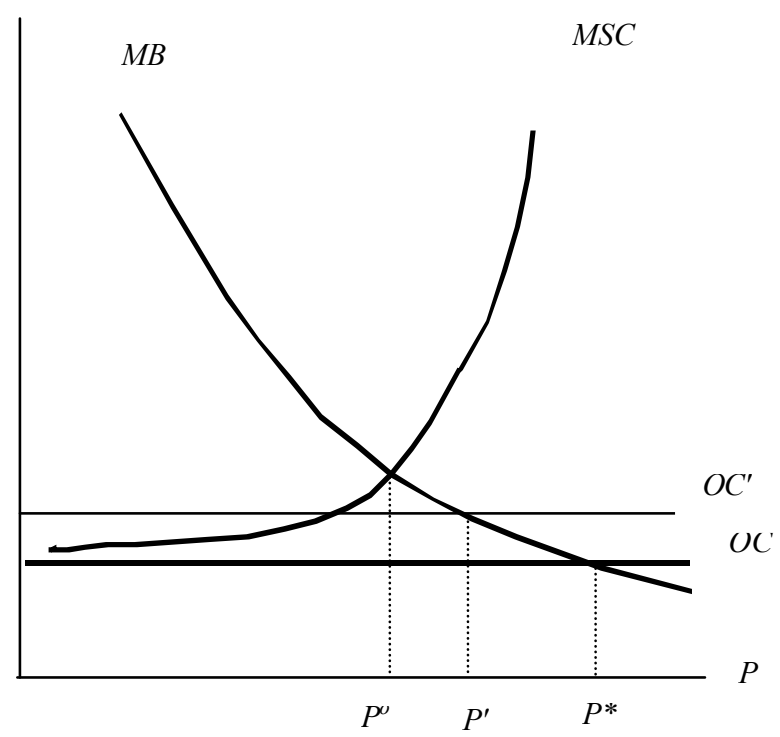

Figure 1: The Public-Sector PTP

The marginal social cost of retirement, however, is in general different from the private opportunity cost above. For simplicity, let us measure this marginal social cost in terms of national output foregone. Then the marginal social cost curve, denoted by MSC in Figure 1, is the inverse of the marginal product of labor. If the marginal product of labor declines as employment increases, then the marginal social cost of retirement must rise as the number of retired people increases. If the marginal product declines at an increasing rate, the marginal social cost increases at an increasing rate, as illustrated in the figure.

The socially optimal retirement level $P^{o}$ lies at the intersection between the marginal benefit curve $M B$ and the marginal social cost curve $M S C$ in Figure 1. When the marginal social cost MSC exceeds the private marginal opportunity cost $O C$ at the equilibrium retirement level $P^{*}$, as shown in the figure, the socially optimal level of retirement is less than the equilibrium level: $P^{o}<P^{*}$.

In this context, the provision of employment vouchers raises the opportunity cost of retiring. After all, the vouchers enable employees to achieve higher wages than they would have otherwise earned, and thus the difference between wage income and pension 
benefits per person rises. Thereby the employment vouchers reduce the equilibrium retirement level. For instance, if the opportunity cost of retiring rises from $O C$ to $O C^{\prime}$, then the equilibrium retirement level falls from $P^{*}$ to $P^{\prime}$.

Now consider the decision whether to impose pension rights or auction early retirement rights. The following proposition provides guidelines for this decision:

Proposition: Suppose that the marginal benefits or the marginal social costs of early retirement are uncertain. Then,

- if the marginal social cost curve is steeper than the marginal benefit curve, then auctioning early retirement rights is preferable to the imposition of pension taxes; and

- if the marginal social cost curve is flatter than the marginal benefit curve, the imposition of pension taxes is preferable to the auctioning of early retirement rights.

To see this, let us define $b(p)$ as the marginal benefits $\left(b^{\prime}<0\right)$ and $c(p)$ as the marginal social cost. Then define $a(p)=b(p)-c(p)$. Deadweight loss when number retiring are $p^{0}$ and optimal number is $p^{*}$ is $\int_{P^{\circ}}^{P^{*}}|a(p)| d t$.

Consider the special case where $a(p)$ is linear. In particular, we define

$$
b(p)=b_{0}-b_{1} p \text { and } c(p)=c_{0}+c_{1} p
$$

In this linear case the problem reduces to determining under which system the number retiring is closest to the equilibrium $p^{*}$.

Suppose that benefits are uncertain so that $b(p)=e+b^{*}(p)$ where $e$ is a random number with mean zero. The optimal number retiring (at which $b(p)=c(p)$ ) is

$$
p^{*}=\frac{b_{0}-c_{0}+e}{b_{1}+c_{1}} .
$$

With early retirement rights calculated as if $\mathrm{e}=0$, the number retiring is

$$
p^{r}=\frac{b_{0}-c_{0}}{b_{1}+c_{1}}
$$

which differs from the optimal level by $\frac{e}{b_{1}+c_{1}}$. 
If, instead of uncertain benefits, there were uncertain costs with $c(p)=-e+c^{*}(p)$ we would achieve the same result.

With taxes fixed at an optimal level for $e=0$, the number retiring solves $e+b(p)-c\left(p^{r}\right)=0$, and the number retiring is

$$
p^{t}=\frac{b_{0}-c_{0}}{b_{1}+c_{1}}+\frac{e}{b_{1}}
$$

The difference between the number retiring and the optimal level is:

$$
\frac{e}{b_{1}+c_{1}} \frac{c_{1}}{b_{1}}
$$

Note that one also obtains the same solution with uncertain costs instead of uncertain benefits.

Thus, if $c_{1} / b_{1}>1$ or the cost curve is steeper than the benefit curve, then the sale of early retirement rights is preferable to pension taxes; and $c_{1} / b_{1}<1$, the imposition of pension taxes is preferable.

To clarify the intuition underlying this result, consider Figures 2 and 3. For simplicity, suppose that the only $M B$ curve is subject to random fluctuations. ${ }^{2}$ In Figure 2a, the curve $E(M B)$ indicates the expected (average) height of the marginal benefit curve. In practice, however, suppose that the curve may lie above this position at $M B_{H}$ (where the subscript $H$ stands for "high") or below this position at $M B_{L}$ (where the subscript $L$ stands for "low"). ${ }^{3}$

Figure 2a shows that when the MSC curve is steeper than the MB curve, then the sale of early retirement rights is preferable to pension taxes. In particular, suppose that the government auctions off $P^{o}$ early retirement rights, where $P^{o}$ also lies at the intersection between the $E(M B)$, curve and the marginal social cost curve $M S C$. Then, if the actual marginal benefit curve is at $M B_{H}$, then the deadweight loss is given by the triangle $S_{H}$, whereas if the actual marginal benefit curve is at $M B_{L}$, the associated deadweight loss is represented by the triangle $S_{L}$.

\footnotetext{
${ }^{2}$ As shown in the appendix, however, our conclusions do not depend on whether the MBor the MSCcurve, or both, are subject to random fluctuations.

${ }^{3}$ The appendix indicates that our conclusions do not depend on the distributions of the random fluctuations.
} 


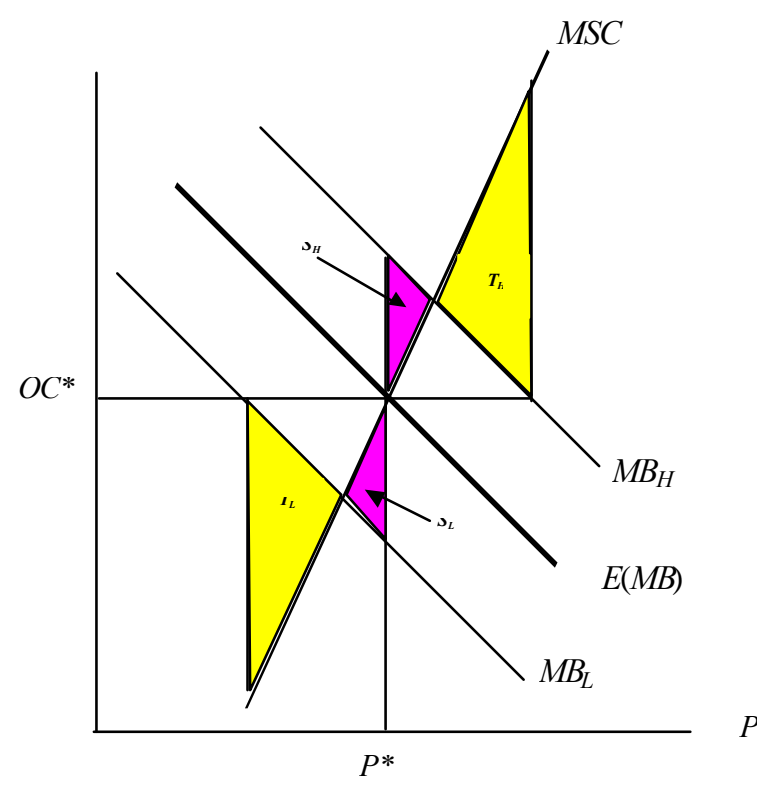

Figure 2a: Early Retirement Rights are Preferable

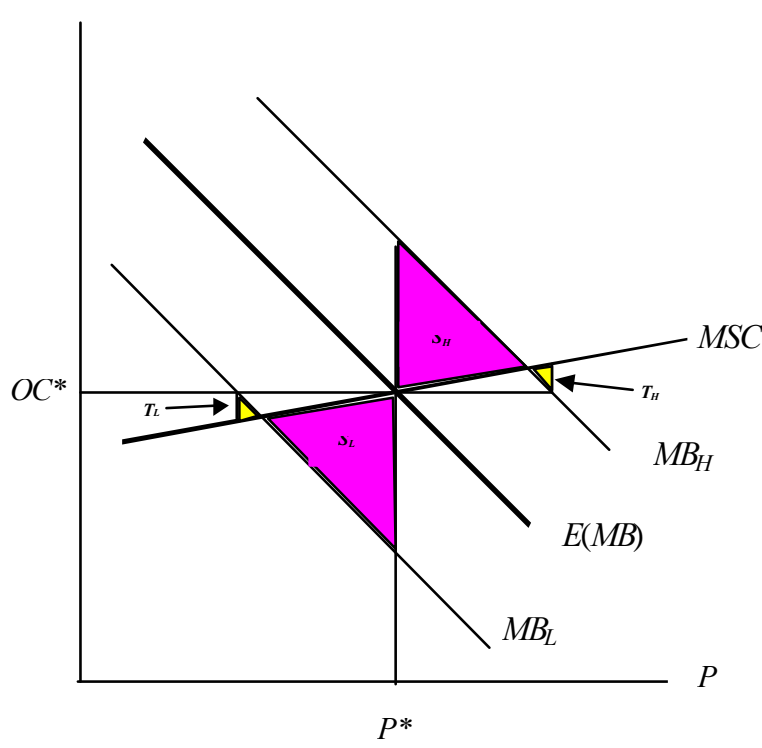

Figure 2b: Pension Taxes are Preferable

Next, suppose that the government sets the tax on pension receipts so that the marginal private opportunity cost curve $O C$ intersects the $E(M B)$ curve exactly where the $E(M B)$, curve intersects the marginal social cost curve $M S C$. Then, if the actual marginal benefit curve is at $M B_{H}$, then the deadweight loss is given by the triangle $T_{H}$, whereas if the actual marginal benefit curve is at $M B_{L}$, the associated deadweight loss is represented by the triangle $T_{L}$.

Since the deadweight triangles $T_{L}$ and $T_{H}$ associated with the pension taxes are larger than the deadweight triangles $S_{L}$ and $S_{H}$, the sale of pension rights is preferable.

Figure $2 b$, on the other hand, illustrates that when the MSC curve is flatter than the $M B$ curve, then pension taxes are preferable. Once again, suppose that the government sets the tax on pension receipts so that the marginal private opportunity cost curve $O C$ goes through the intersection between the $E(M B)$ curve and the $M S C$ curve. Now the deadweight triangles $T_{L}$ and $T_{H}$ associated with the pension taxes are smaller than the deadweight triangles $S_{L}$ and $S_{H}$, associated with the sale of early retirement rights, and thus the sale of rights is preferable. 
Figure 3 incorporates these insights into a general figure picturing a nonlinear marginal social cost curve. This figure illustrates a striking result. When the marginal social cost rises at an increasing rate (as shown in the figure), pension taxes are preferable only when the marginal benefit curve crosses the marginal social cost curve in the lower reaches of the latter curve. But in this region there is unlikely to be a significant discrepancy between the equilibrium and optimal retirement levels, since the marginal private and social costs are likely to be similar in this region. (After all, there are few people on early retirement in this region and thus the corresponding externality is low.)

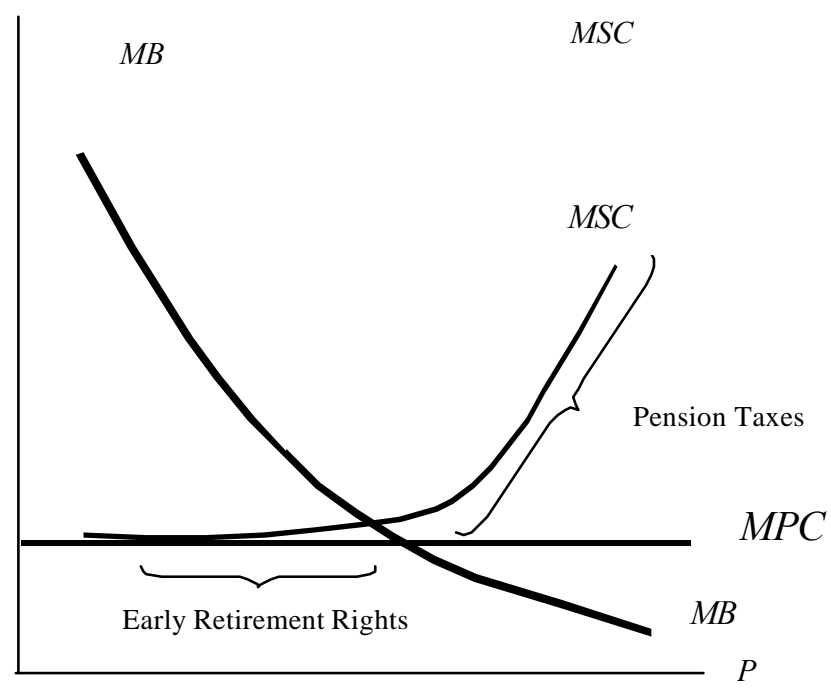

Figure 3: Early Retirement

Rights versus Pension Taxes

On the other hand, when the marginal benefit curve crosses the marginal social cost curve in the upper reaches of the latter curve, the sale of early retirement rights is preferable. Thus the region where the discrepancy between the equilibrium and optimal retirement levels is likely to be significant.

In short, when the marginal social cost rises at an increasing rate, the sale of early retirement rights is preferable to the imposition of pension taxes when the pension-tax externality is significant. Along analogous lines, it can be shown that when the marginal social cost rises at a decreasing rate, the imposition of pension taxes is preferable to the sale of early retirement rights when the pension-tax externality is significant. 


\section{IZA Discussion Papers}

\begin{tabular}{|c|c|c|c|c|}
\hline No. & Author(s) & Title & Area & Date \\
\hline 519 & $\begin{array}{l}\text { S. Cohen } \\
\text { Z. Eckstein }\end{array}$ & $\begin{array}{l}\text { Labor Mobility of Immigrants: Training, } \\
\text { Experience, Language and Opportunities }\end{array}$ & 1 & $06 / 02$ \\
\hline 520 & U. Sunde & $\begin{array}{l}\text { Unobserved Bilateral Search on the Labor } \\
\text { Market: A Theory-Based Correction for a } \\
\text { Common Flaw in Empirical Matching Studies }\end{array}$ & 1 & $06 / 02$ \\
\hline 521 & $\begin{array}{l}\text { U. Sunde } \\
\text { R. Fahr }\end{array}$ & $\begin{array}{l}\text { Employment Status, Endogenous Regional } \\
\text { Mobility, and Spatial Dependencies in Labor } \\
\text { Markets }\end{array}$ & 1 & $06 / 02$ \\
\hline 522 & $\begin{array}{l}\text { S.-Å. Dahl } \\
\varnothing . \text { A. Nilsen } \\
\text { K. Vaage }\end{array}$ & $\begin{array}{l}\text { Gender Differences in Early Retirement } \\
\text { Behaviour }\end{array}$ & 3 & $06 / 02$ \\
\hline 523 & $\begin{array}{l}\text { J. Falkinger } \\
\text { V. Grossmann }\end{array}$ & $\begin{array}{l}\text { Workplaces in the Primary Economy and Wage } \\
\text { Pressure in the Secondary Labor Market }\end{array}$ & 3 & $07 / 02$ \\
\hline 524 & $\begin{array}{l}\text { J. J. Dolado } \\
\text { F. Felgueroso } \\
\text { J. F. Jimeno }\end{array}$ & $\begin{array}{l}\text { Recent Trends in Occupational Segregation by } \\
\text { Gender: A Look Across the Atlantic }\end{array}$ & 2 & $07 / 02$ \\
\hline 525 & $\begin{array}{l}\text { J. J. Heckman } \\
\text { C. Heinrich } \\
\text { J. Smith }\end{array}$ & The Performance of Performance Standards & 6 & $07 / 02$ \\
\hline 526 & $\begin{array}{l}\text { E. Leuven } \\
\text { H. Oosterbeek }\end{array}$ & $\begin{array}{l}\text { A New Approach to Estimate the Wage Returns } \\
\text { to Work-Related Training }\end{array}$ & 6 & $07 / 02$ \\
\hline 527 & J. C. van Ours & The Locking-in Effect of Subsidized Jobs & 4 & $07 / 02$ \\
\hline 528 & $\begin{array}{l}\text { P. Manzini } \\
\text { M. Mariotti }\end{array}$ & $\begin{array}{l}\text { Arbitration and Mediation: An Economic } \\
\text { Perspective }\end{array}$ & 3 & $07 / 02$ \\
\hline 529 & $\begin{array}{l}\text { J. M. Orszag } \\
\text { D. Snower }\end{array}$ & Incapacity Benefits and Employment Policy & 3 & $07 / 02$ \\
\hline 530 & $\begin{array}{l}\text { M. Karanassou } \\
\text { D. Snower }\end{array}$ & Unemployment Invariance & 3 & $07 / 02$ \\
\hline 531 & $\begin{array}{l}\text { M. Karanassou } \\
\text { H. Sala } \\
\text { D. Snower }\end{array}$ & $\begin{array}{l}\text { Unemployment in the European Union: A } \\
\text { Dynamic Reappraisal }\end{array}$ & 3 & $07 / 02$ \\
\hline 532 & $\begin{array}{l}\text { J. M. Orszag } \\
\text { D. Snower }\end{array}$ & $\begin{array}{l}\text { From Unemployment Benefits to Unemployment } \\
\text { Accounts }\end{array}$ & 3 & $07 / 02$ \\
\hline 533 & $\begin{array}{l}\text { S. Fölster } \\
\text { R. Gidehag } \\
\text { M. Orszag } \\
\text { D. Snower }\end{array}$ & Assessing Welfare Accounts & 3 & 07/02 \\
\hline 534 & $\begin{array}{l}\text { A. Lindbeck } \\
\text { D. Snower }\end{array}$ & The Insider-Outsider Theory: A Survey & 3 & 07/02 \\
\hline 535 & $\begin{array}{l}\text { P. Manzini } \\
\text { D. Snower }\end{array}$ & $\begin{array}{l}\text { Wage Determination and the Sources of } \\
\text { Bargaining Power }\end{array}$ & 3 & $07 / 02$ \\
\hline 536 & $\begin{array}{l}\text { M. Orszag } \\
\text { D. Snower }\end{array}$ & Pension Taxes versus Early Retirement Rights & 3 & 7/02 \\
\hline
\end{tabular}

An updated list of IZA Discussion Papers is available on the center's homepage www.iza.org. 